\title{
The Impact of the LCR on the Interbank Money Market
}

\author{
Clemens Bonner ${ }^{\mathrm{a}}$, Sylvester Eijffinger ${ }^{\mathrm{b}}$ \\ ${ }^{a}$ De Nederlandsche Bank, PO Box 98, 1000 AB Amsterdam, The Netherlands \\ ${ }^{b}$ CentER, Tilburg University, PO Box 90153, 5000 LE Tilburg, The Netherlands
}

\begin{abstract}
This paper analyzes the impact of the Basel 3 Liquidity Coverage Ratio (LCR) on the unsecured interbank money market and therefore on the implementation of monetary policy. Combining two unique datasets, we show that banks which are just above/below their short-term regulatory liquidity requirement pay and charge higher interest rates for unsecured interbank loans. The effect is larger for longer maturities. During a crisis, being close to the minimum liquidity requirement induces banks to decrease lending volumes, even when controlling for relationship lending and the solvency of borrowing counterparts. Given the high importance of a well-functioning interbank money market, our results suggest that despite its positive effect on financial stability, the current design of the LCR is likely to dampen the effectiveness of monetary policy.
\end{abstract}

Keywords: Monetary Policy, Liquidity, Interbank Market, Basel 3

JEL classification: G18, G21, E42

\footnotetext{
${ }^{2}$ We would like to thank Jack Bekooij and Richard Heuver for providing data, Leo de Haan, Ronald Heijmans, Iman van Lelyveld, Stefan Schmitz and Jan-Willem van den End for comments and suggestions. This paper represents the authors' opinions and not necessarily those of DNB or Tilburg University. Corresponding author: c.bonner@dnb.nl; +31(0)205242186
} 


\section{Introduction}

Prior to the financial crisis in 2008, asset markets were liquid and funding was easily available at low cost. However, the emergence of the crisis showed how rapidly market conditions can change, leading to a situation that several institutions - regardless of appropriate capital levels - experienced severe liquidity issues, forcing either an intervention by the responsible central bank or a shutdown of the institution.

As response to this crisis, the Basel Committee for Banking Supervision (BCBS) drafted a new regulatory framework ${ }^{1}$ (henceforth Basel 3) with the purpose to achieve a more stable and less vulnerable banking system. Besides new rules for capital and leverage, the framework also specifies a short- and a long-term liquidity requirement as key concepts to reinforce the resilience of banks to liquidity risks. The Liquidity Coverage Ratio (LCR) is a short-term ratio which requires financial institutions to hold high quality liquid assets to meet short-term obligations which are caused by sudden liquidity disruptions. Banks are required to hold an amount of highly liquid assets at least equal to their net cash outflows over a 30-day stress period.

While the purpose of the LCR is straightforward, both its exact setup and the potential unintended side-effects are still controversial. Schmitz (2009), Schmitz (2010) as well as Bindseil and Lamoot (2011) argue that the introduction of the LCR generally sets incentives for banks to decrease lending and borrowing in the unsecured interbank money market due to their high run-off assumption which would require banks to hold large liquidity buffers balancing these outflows. Other observers argue that there would be no direct effect of the LCR on loans with maturities shorter than 30 days which make the largest part of the unsecured interbank money market. The reason for this is that any outflow (inflow) would be compensated by the respective inflow (outflow) within the LCR's 30-day horizon. For loans with maturities longer than 30 days no repayments would occur within the horizon of the LCR and therefore these loans would have a direct effect. In any case, a shrinking of the unsecured interbank money market could hamper the allocation and distribution of

\footnotetext{
${ }^{1}$ See BCBS (2010a) and BCBS (2010b).
} 
liquidity and therefore negatively affect the liquidity risk exposure of banks. Further, Bindseil and Lamoot (2011) argue that due to the reduction of liquidity in the unsecured money market the role of EONIA in monetary policy implementation should be questioned. According to Schmitz (2011), the ECB, the Federal Reserve as well as the Bank of England rely on the interbank money market interest rate as operating targets in monetary policy implementation. This is confirmed by Borio (2001) who shows that central banks implement monetary policy by manipulating the interbank money market interest rates through open market operations and therefore any price or volume movement in the interbank money market could severely affect the effectiveness of monetary policy. However, due to the fact that the interbank market was a critical source of contingent liquidity risk during the recent crisis, some of these implications on the interbank money market are intended and it might be that the positive effects of reducing banks' dependence on the interbank market outweigh its potential negative implications on monetary policy. In 2003, De Nederlandsche Bank (DNB) introduced a quantitative liquidity rule 8028 (henceforth DLCR). ${ }^{2}$ Under the DLCR, a bank's actual liquidity must exceed required liquidity, at horizons of both one week and one month. Using the regulatory liquidity requirement DLCR as proxy for the LCR in combination with confidential data on interbank borrowing and lending in the Dutch interbank market, a set of controls accounting for the riskiness of an institution and its business model, the purpose of this paper is to show whether the introduction of a quantitative liquidity rule leads to higher interest rates and lower lending volumes in the unsecured interbank money market. This paper adds to the literature as it is the only study, which provides empirical evidence on the impact of a quantitative liquidity rule on the interbank money market and therefore on the implementation of monetary policy.

The main results can be summarized as follows: A bank which is just above/below its minimum liquidity requirement asks and pays higher interest rates for loans in the unsecured interbank money market. These results also hold when controlling for an institution's riskiness, the solvency of its counterparts, relationship-lending, size and business model. Both effects are larger for maturities longer than the

\footnotetext{
${ }^{2}$ See DNB (2003).
} 
30-day horizon of the LCR. During stress, being just above/below the prudential liquidity requirement induces a negative impact on lending volumes.

\section{Literature Review}

Starting with the collapse of Lehman Brothers on September 15th 2008, the world has been subject to a global financial crisis, which affected all economies around the globe. Since then, there has been a debate about causes, consequences and possible countermeasures. ${ }^{3}$ Apart from its geographical dimension, the great interest in this crisis also mitigated a discussion about the fundamental fragility and vulnerability of the financial system as such.

Giavazzi and Giovannini (2011) argue for instance that the fragility of financial markets mainly stems from their role for liquidity transformation. Liquidity transformation links the financing of long-term funding for productive investments via the pooling of agents with different transactional needs. However, once many short-term depositors want to withdraw their money simultaneously, the value of liquid investments is likely to fall short compared to short-term debt. A bank-run materializes with severe consequences for the stability of the financial market and society as such. According to the seminal contribution of Diamond and Dybvig (1983) banks are forced into fire sales due to the ability of depositors to withdraw their funds, exposing banks to self-fulfilling panics. Once the funding for longterm projects dries up, production will be less efficient resulting in lower income for everybody.

Illustrating the issue of liquidity transformation and the fragility of financial markets with several examples based on Holmstrom and Tirole (2011) as well as Diamond and Dybvig (1983), Giavazzi and Giovannini (2011) argue that the main challenge of regulators is to minimize the likelihood of liquidity transformation to break down.

Since the announcement of the BCBS to introduce new regulations for capital and liquidity, several streams of academic and policy-oriented literature have been discussing possible long- and short-term impacts of the reform. MAG (2010a) and

\footnotetext{
${ }^{3}$ See for instance Reinhart and Rogoff (2008), Crotti (2009), Diamond and Rajan (2009) and Hume and Sentance (2009).
} 
MAG (2010b) assess the macroeconomic impact of tighter capital and liquidity requirements during the transition phase. Modeling the direct effect of a liquidity rule as a $25 \%$ increase in the holding of liquid assets combined with increased maturities of banks' wholesale liabilities, the authors find a 14 basis point increase in the median lending spread and a fall in lending volumes of 3.2\%. Analyzing the duration of the transition period, the studies find a negative relation between magnitude of the effects and duration of the transition period. Both studies fail to take into account that by definition new liquidity regulations (should) lead to stronger and more stable banks which might lower their funding costs and therefore dampen the increase in lending spreads and other negative side effects. Further, banks will seek to improve their efficiency and therefore cutting non-interest expenses, which in turn might lower the increase in lending spreads. On the other hand, the increased demand for liquid assets could possibly increase the price and therefore the costs to meet the liquidity rules.

Recent microeconomic studies concerning banks' liquidity management have focussed on several aspects such as the management of reserve requirements (Bartolini et al. (2001), Jallath-Coria et al. (2002)), the transformation of short-term liabilities into liquid assets (Berger and Bouwman (2009)) as well as securities holdings and cash balances (Aspachs et al. (2005), Freedman and Click (2009)). The way banks manage their overall liquidity under a quantitative liquidity requirement is shown in De Haan and Van den End (2012) as well as Schertler (2010).

However, there exists no study which analyzes the direct impact of a quantitative liquidity rule on the unsecured interbank money market. The purpose of this paper is to provide empirical evidence on banks' behavior in the interbank market depending on their (non)-fulfilment of their regulatory liquidity requirement.

\section{Data description}

In order to analyze the effects of a quantitative liquidity requirement on the unsecured interbank money market, we bring together data on 1) DNB's monthly prudential liquidity reporting, 2) bilateral transactions in the interbank market for different maturities (volumes and prices) and 3) risk indicators and other measures calculated from the balance sheet. We will discuss these data sources in turn. 


\subsection{Dutch Liquidity Coverage Ratio (DLCR)}

As proxy of the LCR, we examine banks' liquidity holdings using monthly data of the prudential Dutch quantitative liquidity rule DLCR. Under the DLCR, a bank's actual liquidity must exceed required liquidity, at horizons of both one week and one month. For the purpose of this analysis, we calculate ratios of actual over required liquidity. Actual liquidity is defined as the stock of liquid assets minus haircuts plus recognized cash inflows weighted by degree of liquidity. Required liquidity is defined as the assumed calls on contingent liquidity lines, assumed withdrawals of deposits, assumed drying up of wholesale and derivative funding. The current legislation of the DLCR allows banks to include Residential Mortgage Backed Securities (RMBS) as part of the liquidity buffer while the LCR does not allow the inclusion of RMBS. Further, with respect to deposits and contrary to the DLCR, the LCR distinguishes "stable" and "less stable" deposits which have different run-off rates under stress and are classified according to a set of predefined conditions. In order to limit the resilience on estimated inflows, the BCBS capped inflows to a maximum of $75 \%$ of outflows while the DLCR takes into account inflows to a full extent. ${ }^{4}$

The treatment of interbank loans is equal under the LCR and the DLCR. In case of loans with maturities less than 30 days, there is likely to be no direct effect on either the LCR or the DLCR. If institution A receives a loan from institution B with a maturity of less than 30 days, the increase of institution A's liquidity buffer is offset by an increase of its cash outflows within the LCR's 30 day horizon. Similarly, institution B's declined liquidity buffer is compensated by a cash inflow from institution A's loan repayment. ${ }^{5}$ In case of loans with maturities longer than 30 days neither inflows nor outflows occur within the LCR's 30 day horizon which leads to a situation that the borrowing bank can increase its liquidity buffer and therefore its LCR while institution B's LCR will decline.

Limited by the number of banks active in the interbank money market, we use data for 61 Dutch banks from January 2004 to December 2011. To gain insight

\footnotetext{
${ }^{4}$ For a more in depth description of the DLCR, please refer to De Haan and Van den End (2012).

${ }^{5}$ For completion it needs to be mentioned that in contrast to the DLCR, the LCR cannot increase in case the institution is affected by the cap on inflows.
} 
in whether the introduction of a quantitative liquidity requirement affects the interbank money market, we create a dummy which is 1 in case a bank's DLCR is between $90 \%$ (just below) and $110 \%$ (just above) and 0 otherwise. Over the whole sample period, we have 2391 observations and 536 cases (22\%) in which a bank's liquidity ratio is between $90 \%$ and $110 \%$. The average time a bank remains close to the requirement is 4.4 months, with a median of 2 months, a maximum of 54 and a minimum of 1 month.

\subsection{Interbank Market}

The interbank market works as an over-the-counter (OTC) market so prices and volumes are not publicly known. Financial institutions settle various types of payments in TARGET 2 (the interbank payment system of cross-border transfers within the EU), such as payments on behalf of customers, bank-to-bank payments, payment of the cash leg of a security trade, and pay-ins for the CLS system (continuous linked settlement) to settle foreign exchange transactions. In 2010, the Dutch part of TARGET 2 had 61 direct participants including a few large British banks, a daily average of 34.000 transactions and a daily turnover of 295 billion euro. The Dutch part of TARGET 2 constitutes roughly $13 \%$ (10\%) of the complete TARGET system in terms of volume (transactions).

In a recent paper, Heijmans et al. (2010) describe how, based on these flows, loans can be identified and thus volumes and prices extracted. The authors build on the seminal paper by Furfine (1999) and improve the algorithm to include durations of up to one year. ${ }^{6}$ The algorithm has been applied in the US using Fedwire (Demiralp et al. (2006), Ashcraft and Bleakley (2006), Hendry and Kamhi (2009)), Norway (Akram and Christophersen (2010)), and Germany (Braeuning (2011)).

The algorithm returns information on the borrowing and lending institution, paid interest rates, total value as well as maturity of the loan. We create monthly volume weighted averages of the interest rates per bank to calculate spreads with the respective ECB interest rate and monthly sums of the traded loans times maturity divided by total assets.

\footnotetext{
${ }^{6}$ For a more detailed description of the functioning of the algorithm, see Heijmans et al. (2010).
} 


\subsection{Balance Sheet}

Alongside with the new requirements for liquidity, the BCBS tightened the capital rules and newly introduced a leverage ratio. To map the new Basel requirements into the regression, we introduce a leverage ratio, which is defined as equity over total assets and a capital ratio which reflects the ratio of capital over risk weighted assets. For both of these measures we use (interpolated) monthly data per bank from January 2004 to December 2011 from DNB's prudential reporting.

Following a recent working paper by Hilscher and Wilson (2012) who show that a set of easily obtainable balance sheet measures outperform professional credit ratings and cds spreads, we include return on equity, profitability defined as the percentage of income over total assets and cash flows ${ }^{7}$ reflected by the percentage of cash over total assets to control for the riskiness of an institution. By definition the variables referring to Basel III, leverage and capital, are measures of solvency and therefore also reflect the riskiness of an institution. All variables are obtained from DNB's prudential reporting and cover January 2004 until December 2011.

The rationale behind including such a large amount of variables controlling for the riskiness of an institution is that there is broad consensus that a bank's activity in the interbank market is at least partially driven by its perceived riskiness. Therefore, controlling for the riskiness of an institution is essential when analyzing the interbank market. A further reason to include return on equity and profitability is that these variables are correlated with the overall state of the economy which makes them suitable candidates to control for the possibility that the dependent variables and liquidity as the key independent variable are jointly driven by the current economic situation.

\subsection{The Interbank Market before and after the failure of Lehman Brothers}

In a recent working paper Heijmans et al. (2010) analyze the Dutch interbank market, based on four periods: 1) January 2004 until June 2007: financial markets were smooth and well-functioning, 2) July 2007 until August 2008: first turmoils,

\footnotetext{
${ }^{7}$ There have been some concerns regarding multicollinearity. However, the correlation coefficients between the riskiness and the liquidity variables are relatively low (with 0.273 being the highest), which implies that multicollinearity does not seem to be an issue here.
} 
3) September 2008 until June 2009: failure of Lehman Brothers, followed by a severe period of stress and 4) July 2009 until December 2011: Unconventional monetary policy measures by the ECB. Looking at the developments in the interbank market and following the general policy discussions, it is sensible to simplify the distinction in a period before and a period after the the failure of Lehman Brothers.

Comparing the average interest rates paid in the Dutch interbank market with EONIA it becomes evident that before the failure of Lehman Brothers, the Dutch interest rate is highly correlated with EONIA. However, after the collapse of Lehman Brothers, the interest rates in the Dutch interbank market increase to a smaller extent than the European average, suggesting that the effect of Lehman Brother's failure is somewhat smaller for Dutch banks compared to the European average. Still and similar to the findings of Gorton (2009), the volatility and spreads of the interest rates increase considerably after the failure due to higher risk aversion in the market. Heijmans et al. (2010) find that the spreads of the Dutch interest rates increase from 7.1 basis points before the failure to 18.6 basis points after the failure of Lehman Brothers.

The average total turnover calculated as the sum of the total value of a loan times its maturity for maturities longer than 30 days decreases from EUR 3.8 billion in the period before the failure to EUR 2.64 billion in the period after the failure. The first upward trends can be observed in the summer of 2009. In this period, the ECB started injecting extra liquidity using unconventional monetary policy measures.

Summarizing, it can be seen that the credit crunch after the failure of Lehman Brothers led to higher interest rates, higher volatilities and lower volumes. Although the Dutch interbank market did not completely vanish and remained sufficiently active, it needs to be mentioned that a drawback of our analysis is that periodically the results might be heavily influenced by only a small number of banks. However, those banks which remain active in a relatively inactive market can be considered to be overproportionately strong and therefore (if anything) our results underestimate the effects of the quantitative liquidity requirement. 


\section{The Model}

For the entire analysis, we apply panel regressions with fixed effects. Apart from the results of the Hausman test, the choice for fixed instead of random effects has three reasons: First, if the individual effect represents omitted variables, it is highly likely that these bank-specific characteristics are correlated with the other regressors and therefore our fixed effects estimation helps us to partially eliminate endogeneity problems. Second, we want to analyze the adjustments of banks' behavior in the time variation and not in the cross-sectional variation of the data and third, our panel dataset includes very large to very small banks with large variations with respect to business models which in turn implies that differences among banks are not random. All employed models have the common feature that they rely on the fulfilment of the prudential quantitative liquidity requirement. The baseline equation takes the following form:

$$
\begin{gathered}
Y_{i, t}=\beta_{0}+\beta_{1} L O W_{i, t}+\beta_{2} M_{i, t}+\beta_{3} R L A T_{i, t}+\beta_{4} C C P_{i, t}+\beta_{5} C_{i, t}+\beta_{6} R_{i, t}+\varepsilon_{i, t} \\
\text { with } \varepsilon_{i, t}=\mu_{i}+\eta_{i, t}
\end{gathered}
$$

where $Y_{i, t}$ describes the dependent variable which is either the spread between the volume weighted average of the monthly interest rate charged (paid) by an institution when lending (borrowing) in the unsecured interbank money market with the respective ECB rate or the ratio of a bank's monthly total lending over total assets. The dummy variable $L O W_{i, t}$ allows us to gain insight whether a bank which is just above/below its regulatory liquidity requirement behaves differently in the interbank money market. The variable is 1 in case a bank's liquidity ratio is between $90 \%$ and $110 \%$ and 0 otherwise. This approach is in line with other studies dealing with the impacts of prudential regulation (Shrieves and Dahl (1992), Schertler (2010)). ${ }^{8}$

\footnotetext{
${ }^{8}$ The rationale behind using a dummy instead of a continuous variable is that we would like to capture the direct effect of the fulfilment of the quantitative liquidity requirement instead of using a proxy for the liquidity position of an institution. The disadvantage of our dummy is that we are not able to distinguish between the behavioral changes of those banks which are still relatively close
} 
$M_{i, t}$ is a vector giving more insight into the exact composition of the dependent variables. It includes LongLen reflecting the share of loans with maturities longer than 30 days over total loans and an interaction term of LOW and LongLen. This setup allows us to separate the general effects of a quantitative liquidity rule from the effects on loans with maturities longer than 30 days.

$R L A T_{i, t}$ is based on Cocco et al. (2009) and describes the relationships and the importance of an institution in the interbank money market. $R L A T_{i, t}$ is calculated as an institution's monthly lending to its individual borrowing counterparts as share of the borrowing institutions' total borrowing (which reflects the importance of the lending bank for its individual counterparts and follows the borrower preference index in Cocco et al. (2009)) weighted by the share of the issuing institution's lending to its respective individual counterparts divided by the issuing institution's total lending (which reflects the importance of the borrowing bank for its lending counterpart and corresponds to the lender preference index, introduced by Cocco et al. (2009)). ${ }^{9}$

Another essential variable is $C C P_{i, t}$ which reflects the monthly volume weighted average capital ratio of an institution's counterparts. The rationale behind including this control variable is that the choice of the counterpart is likely to influence the charged interest rate. If a bank lends excessively to relatively risky institutions, it is likely to charge higher interest rates.

$C_{i, t}$ includes a dummy (crisis) which is 1 after the failure of Lehman Brothers and 0 otherwise alongside with an interaction term of $L O W$ and crisis. Finally, $R_{i, t}$ is a vector of risk variables ${ }^{10}$, namely profitability, cash-flow and return-on-equity as

to the threshold and the ones very far away. In order to account for this issue, we include in our sensitivity checks the ratio of the DLCR as continuous variable.

${ }^{9}$ To clarify, consider the following example: Bank A lends an amount of 10 to Bank B. Bank A's total lending in the respective month is 20 while Bank B's total monthly borrowing is 100 . We therefore calculate $0.5(=10 / 20) * 0.1(=10 / 100)=0.05$. In order to determine Bank A's importance as a lender, we sum up the outcomes of the same calculation for all its individual counterparts. For the calculation of an institution's importance as borrower, the same calculation applies while exchanging borrowing and lending volumes.

${ }^{10}$ In order to keep the focus on the liquidity requirement, we present in the body of the paper only the results when controlling for the profitability of an institution. In the Appendix several robustness checks are presented in which we control for different combinations of risk indicators. 
well as the Basel 3 measures leverage and regulatory capital. ${ }^{11}$ As we use fixed effects estimations, we also model a bank specific effect $\mu_{i}$ and an iid disturbance term $\eta_{i, t} .^{12}$

\section{Results}

\subsection{Lending Rates}

Table 1 shows that banks which are just above/below ( $L O W)$ their minimum liquidity requirement DLCR charge higher interest rates than their peers for unsecured interbank loans. This effect is particularly large for loans with maturities longer than the LCR's 30 day horizon (LongLenLOW).

Column 1 shows that $L O W$ banks charge 22 basis points more than their peers for unsecured interbank loans. This result is robust to adding the variable crisis (dummy which is 1 after the failure of Lehman Brothers and 0 otherwise) as well as $L O W$ crisis (interaction term of $L O W$ and crisis). The variable crisis is significant, suggesting that banks charge 52 basis points less when lending during a recession. While the negative sign of crisis seems to be counterintuitive at first, it needs to be mentioned that we calculate spreads between the actual weighted interest rate and the respective ECB interest rate. Therefore, crisis suggests that the spread between the two rates is 52 basis points smaller during crises. An explanation for this is that after the failure of Lehman Brothers only a few banks remained active in the interbank money market. It can be assumed that the remaining institutions were more stable and were therefore able to borrow and lend at rates closer to the ECB interest rate. This explanation also holds on the international level given that Dutch banks were considered to be relatively stable compared to their international peers. Interestingly this does not hold for $L O W$ banks as shown by the insignificance of LOW crisis.

\footnotetext{
${ }^{11}$ See BCBS (2010b)

${ }^{12}$ It is well established that the behavior of banks in the unsecured interbank money market is driven by a combination of solvency, general riskiness of the lending and the borrowing institution, the state of the economy and relationships. Controlling for all these variables minimizes the risk that our dependent variable is correlated with the error term and therefore the risk that our analysis suffers from endogeneity.
} 
Table 1: Effects of a quantitative liquidity rule on the Lending Rates in the interbank money market

\begin{tabular}{|c|c|c|c|c|c|c|}
\hline \multirow{2}{*}{ VARIABLES } & $\begin{array}{l}(1) \\
\mathrm{FF}\end{array}$ & $\begin{array}{l}(2) \\
\mathrm{FE}\end{array}$ & $\begin{array}{l}(3) \\
\mathrm{FF}\end{array}$ & $\begin{array}{l}(4) \\
\mathrm{FE}\end{array}$ & $\begin{array}{l}(5) \\
F F\end{array}$ & $\begin{array}{l}(6) \\
F F\end{array}$ \\
\hline & & & & & & \\
\hline \multirow[t]{2}{*}{ LOW } & $0.224 * * *$ & $0.164 * * *$ & $0.178 * * *$ & $0.103 * *$ & $0.111 * *$ & $0.112 * *$ \\
\hline & $(0.0280)$ & $(0.0263)$ & $(0.0516)$ & $(0.0523)$ & $(0.0557)$ & $(0.0558)$ \\
\hline \multirow[t]{2}{*}{ LOWcrisis } & & 0.0473 & 0.0488 & 0.0554 & -0.00560 & -0.00876 \\
\hline & & $(0.0585)$ & $(0.0621)$ & $(0.0622)$ & $(0.0725)$ & $(0.0726)$ \\
\hline \multirow[t]{2}{*}{ crisis } & & $-0.522 * * *$ & $-0.490 * * *$ & $-0.481 * * *$ & $-0.490 * * *$ & $-0.505 * * *$ \\
\hline & & $(0.0237)$ & $(0.0267)$ & $(0.0269)$ & $(0.0276)$ & $(0.0340)$ \\
\hline \multirow[t]{2}{*}{ LongLen } & & & $0.135 * * *$ & $0.146 * * *$ & $0.140 * * *$ & $0.141 * * *$ \\
\hline & & & $(0.0351)$ & $(0.0364)$ & $(0.0364)$ & $(0.0364)$ \\
\hline \multirow[t]{2}{*}{ LongLenLOW } & & & $0.259 * * *$ & $0.242 * * *$ & $0.239 * * *$ & $0.241 * * *$ \\
\hline & & & $(0.0786)$ & $(0.0793)$ & $(0.0851)$ & $(0.0851)$ \\
\hline \multirow[t]{2}{*}{ RLAT } & & & & $-0.319 * * *$ & $-0.212 * * *$ & $-0.234 * * *$ \\
\hline & & & & $(0.0597)$ & $(0.0652)$ & $(0.0713)$ \\
\hline \multirow[t]{2}{*}{ Capital } & & & & & 0.000226 & 0.000220 \\
\hline & & & & & $(0.000206)$ & $(0.000206)$ \\
\hline \multirow[t]{2}{*}{$\mathrm{CCP}$} & & & & & $-0.118 * * *$ & $-0.117 * * *$ \\
\hline & & & & & $(0.0368)$ & $(0.0369)$ \\
\hline \multirow[t]{2}{*}{ RLATcrisis } & & & & & & 0.0992 \\
\hline & & & & & & $(0.128)$ \\
\hline \multirow[t]{2}{*}{ Constant } & $0.798 * * *$ & $0.889 * * *$ & $0.806 * * *$ & $0.851 * * *$ & $0.873 * * *$ & $0.875 * * *$ \\
\hline & $(0.0104)$ & $(0.0101)$ & $(0.0213)$ & $(0.0245)$ & $(0.0266)$ & $(0.0268)$ \\
\hline Observations & 2204 & 2204 & 1711 & 1621 & 1503 & 1503 \\
\hline $\mathrm{R} 2$ & 0.0288 & 0.231 & 0.248 & 0.266 & 0.277 & 0.278 \\
\hline \multicolumn{7}{|c|}{ 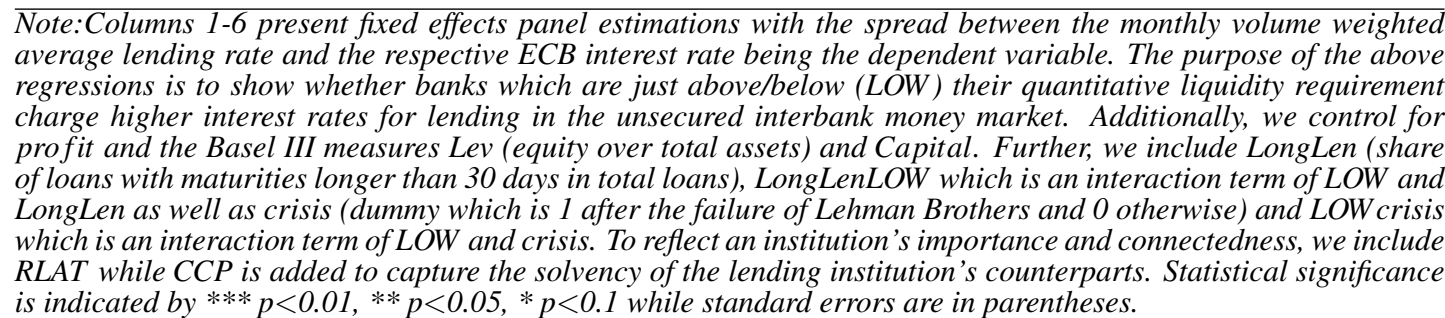 } \\
\hline
\end{tabular}


Column 3 shows that these results continue to hold when adding LongLen (share of loans with maturities longer than 30 days in total loans) and LongLenLOW (the interaction term of $L O W$ and LongLen). LongLenLOW enters the regression significantly on the $1 \%$ level, suggesting that a bank which is just below/above its quantitative liquidity requirement charges 2.6 basis points more in case the share of loans with maturities longer than 30 days increases by 10\%. While LongLen is significant as well, the increasing effect of longer maturities is larger for $L O W$ banks in all specifications. This result suggests that $L O W$ banks are particularly hesitant to issue loans with maturities longer than the LCR's 30 day horizon. The results in column 2 and 3 are a first indication that a quantitative liquidity rule affects the interest rate in the unsecured interbank market in general but especially for longer maturities. This result is straightforward given that we can assume that for maturities longer than 30 days both effects hold, the general direct effect of a quantitative liquidity rule on the interbank market and a specific effect on loans with maturities longer than 30 days.

These results are robust to adding $R L A T$. Our results with respect to RLAT suggest that relationships are an important factor when determining the lending rate in the unsecured interbank money market. RLAT enters all regressions statistically significant with negative sign, suggesting that more important institutions charge lower interest rates.

In Column 5, we add the variable Capital and $C C P$ to the estimation equation. While Capital is insignificant, our results with respect to $C C P$ suggest that an increase of $C C P$ of 1 unit decreases the lending rate by 12 basis points. However, increases of $C C P$ by 1 unit are not observable and the average institution does not change its $C C P$ by more than 0.1 unit implying an increase of the lending rate by 1.2 basis points. Even when controlling for the riskiness of both the lending and the borrowing institution, the compliance with the prudential liquidity requirement remains significant at the $5 \%$ level.

Column 6 additionally includes RLATcrisis, an interaction term of RLAT and crisis. RLATcrisis enters the specification insignificant, suggesting that an institutions can only rely on relationships during normal times but not during stress. Summarizing, our results suggest that $L O W$ banks charge significantly higher interest rates than their peers, even when controlling for relationship-lending, counterpart- 
solvency and own riskiness. While being in a crisis lowers the surcharges on lending in general, this does not hold for $L O W$ banks. Further, the effects of being $L O W$ are particularly large for longer maturities.

\subsection{Borrowing Rates}

Given the high correlation of the lending and borrowing rates of 0.8 and the implied similarity of results, we do not discuss the borrowing rates in detail but just point out the overall results and most important differences.

Generally speaking, $L O W$ banks pay higher interest rates than their peers in the unsecured interbank money market. The effect of being in a crisis has a similar effect for borrowing and lending rates while the effect of longer maturities is smaller for the borrowing rates. In contrast to the lending rates, $L O W$ banks do not pay significantly higher interest rates for longer maturities. Similar to the lending rates, our results confirm that relationships are an important factor in the unsecured interbank money market which significantly lowers the rates to which an institution is able to borrow.

The effect of the variables reflecting the riskiness of an institution have similar effects on borrowing and lending rates. Therefore, even when controlling for the riskiness of an institution, the compliance with the prudential liquidity requirement remains a significant factor when determining an institution's borrowing rate in the unsecured interbank money market.

This is an essential part of our analysis. The interest rate a bank has to pay in the interbank market is the outcome of negotiations between the two counterparts. As in any other contract, there is some sort of asymmetric information. Given the high sensitivity, it is reasonable to assume that a bank's regulatory liquidity position is not known to the lending bank while it will be able to obtain some basic information about the riskiness of its counterpart. In our model the riskiness is reflected by profitability, leverage and capital. Hence, if we control for the riskiness of an institution and its relationships with other banks, which usually determine the borrowing rate in the interbank market, we can conclude that the higher interest rates of $L O W$ banks are caused by the willingness of these banks to pay higher prices and not by the behavior of the lending bank. This conclusion is additionally confirmed by the nature of our fixed effects estimation which estimates adjustments of 
banks' behavior in the time variation and not in the cross-sectional variation. It is highly unlikely that the lending bank can obtain information about its counterpart's fulfilment of the liquidity requirement over time but not of the before-mentioned balance sheet measures.

\subsection{Total Lending}

Table 2 shows that during crises, $L O W$ banks lend considerably less than their peers even when having close relationships with other banks. While maturities do not have a major effect on Lending, relationships and the counterparty solvency are an important factor for Lending.

Column 1 shows that $L O W$ does not have an individually significant effect on Lending. Including however the interaction term LOWcrisis in column 2 shows that the fulfilment of the quantitative liquidity requirement has a significant effect on Lending after the failure of Lehman Brothers. During stress, LOW banks lend $45 \%$ less than their peers while there is no particular crisis effect on the other banks. Similar to the regressions with respect to the interest rates, we add LongLen and LongLenLOW in column 3. While LongLenLOW enters all regressions insignificant, LongLen has a negative impact on Lending. Our results suggest that an increase of loans with maturities longer than 30 days by $10 \%$, decreases Lending $1.6 \%$. These results are robust to adding RLAT. Our results with respect to the relationships of an institution suggest that while close relationships seem to have a negative impact on Lending in general, during crises there is no significant effect. While the negative sign of $R L A T$ is somewhat surprising, a possible explanation can be that during normal times funding from different counterparts is relatively easy available which makes banks relying less on relationship lending.

Adding $C C P$ (reflecting the solvency of an institution's counterparts) significantly decreases the coefficients of LOWcrisis and RLAT . CCP has a statistically significant positive effect on Lending, suggesting that an increase of the counterpart's solvency by 1 unit, increases Lending by $14 \%$.

These results are robust to additionally including RLATcrisis which enters all regressions insignificant. 
Table 2: Effects of a quantitative liquidity rule on banks' lending volumes

\begin{tabular}{|c|c|c|c|c|c|c|}
\hline \multirow{2}{*}{ VARIABLES } & $\begin{array}{l}(1) \\
\mathrm{FF}\end{array}$ & $\begin{array}{l}(2) \\
\mathrm{FE}\end{array}$ & $\begin{array}{l}(3) \\
\mathrm{FE}\end{array}$ & $\begin{array}{l}(4) \\
\mathrm{FE}\end{array}$ & $\begin{array}{l}(5) \\
\mathrm{FE}\end{array}$ & $\begin{array}{l}(6) \\
\mathrm{FE}\end{array}$ \\
\hline & & & & & & \\
\hline \multirow[t]{2}{*}{ LOW } & -3.402 & 2.545 & -5.701 & 4.849 & 5.048 & 5.288 \\
\hline & $(8.429)$ & (8.879) & (13.80) & (14.03) & $(9.262)$ & $(9.276)$ \\
\hline \multirow[t]{2}{*}{ LOWcrisis } & & $-45.10 * *$ & $-64.34 * * *$ & $-63.57 * * *$ & $-17.26 * * *$ & $-20.28 * * *$ \\
\hline & & $(19.70)$ & (16.59) & (16.69) & $(4.580)$ & (5.792) \\
\hline \multirow[t]{2}{*}{ crisis } & & 5.317 & 9.145 & 11.09 & 2.311 & 4.832 \\
\hline & & (7.993) & $(7.136)$ & (7.229) & (12.04) & $(15.07)$ \\
\hline \multirow[t]{2}{*}{ LongLen } & & & $-15.95 *$ & $-16.78 *$ & $-20.01 * * *$ & $-19.71 * * *$ \\
\hline & & & $(9.422)$ & $(9.790)$ & $(6.060)$ & $(6.073)$ \\
\hline \multirow[t]{2}{*}{ LongLenLOW } & & & 21.25 & 8.328 & -0.0101 & 0.499 \\
\hline & & & (21.01) & (21.28) & (14.13) & (14.15) \\
\hline \multirow[t]{2}{*}{ RLAT } & & & & $-61.92 * * *$ & $-21.14^{*}$ & $-25.03 * *$ \\
\hline & & & & (16.03) & $(10.85)$ & (11.87) \\
\hline \multirow[t]{2}{*}{ Capital } & & & & & -0.0134 & -0.0144 \\
\hline & & & & & $(0.0342)$ & $(0.0342)$ \\
\hline \multirow[t]{2}{*}{$\mathrm{CCP}$} & & & & & $13.94 * *$ & $14.15 * *$ \\
\hline & & & & & $(6.121)$ & (6.129) \\
\hline \multirow[t]{2}{*}{ RLATcrisis } & & & & & & 19.46 \\
\hline & & & & & & $(22.82)$ \\
\hline \multirow[t]{2}{*}{ Constant } & $87.02 * * *$ & $86.04 * * *$ & $63.78 * * *$ & $70.40 * * *$ & $57.25 * * *$ & $57.57 * * *$ \\
\hline & (3.138) & (3.439) & $(5.731)$ & $(6.632)$ & $(4.454)$ & $(4.478)$ \\
\hline Observations & 2182 & 2182 & 1691 & 1601 & 1483 & 1483 \\
\hline $\mathrm{R} 2$ & 0.043 & 0.0826 & 0.111 & 0.119 & 0.130 & 0.131 \\
\hline \multicolumn{7}{|c|}{$\begin{array}{l}\text { Note: Columns 1-6 present fixed effects panel estimations with the percentage of total lending over total assets as } \\
\text { dependent variable (henceforth Lending). Total lending is calculated as the monthly sum of loan value multiplied } \\
\text { by maturity. The purpose of the above regressions is to show whether banks which are just above/below (LOW) } \\
\text { their quantitative liquidity requirement lend smaller volumes than their peers. Additionally, we control for Basel } \\
\text { III measures Capital, LongLen (share of loans with maturities longer than } 30 \text { days over total loans), LongLenLiqu } \\
\text { (interaction term of LOW and LongLen), crisis (dummy which is } 1 \text { after the failure of Lehman and } 0 \text { otherwise) } \\
\text { and LOW crisis (interaction term of LOW and crisis). To reflect an institution's importance and connectedness, we } \\
\text { include RLAT while CCP is added to capture the solvency of the lending institution's counterparts. Finally, we } \\
\text { included RLATcrisis which is an interaction terms of RLAT and crisis. Statistical significance is indicated by *** } \\
p<0.01, * * p<0.05, * p<0.1 \text { while standard errors are in parentheses. }\end{array}$} \\
\hline
\end{tabular}




\section{Sensitivity Tests}

In this section we present the sensitivity tests which we conducted to show the robustness of our results. In order to take into account the effects of the general liquidity position of a bank but also the difference between banks which are still relatively close to the minimum liquidity requirement and banks far away from meeting the threshold, we include the actual ratio of the liquidity requirement as continuous variable. Further, we split the dataset in large and small banks and finally re-run our model using a larger set of controls.

Adding a larger set of control variables changes the overall results with respect to interest rates not considerably. Unexpectedly, it reduces somewhat the coefficients and the significance of $L O W$ and LongLenLOW. However, all the variables related to the fulfilment of the DLCR remain economically and statistically significant. Further, the additionally included variables controlling for the riskiness of an institution are all significant without changing the overall results considerably. The continuous variable of the liquidity requirement $(L R M)$ does not have a dominant effect and is only statistically significant in one specification with economically small coefficient. Dividing the dataset in small and large banks yields relatively small changes while the effect of being just above/below the DLCR is slightly larger for bigger banks.

With respect to lending volumes, the effect of additional control variables is somewhat bigger. While $L O W$ as well as LongLenLOW remain statistically insignificant, LOW crisis loses some of its statistical but gaining some economic significance. Interestingly, $L R M$ is generally significant on the $1 \%$ level, having a positive effect on Lending. A possible explanation for the large impact of the continuous liquidity ratio on total lending while there is almost no effect on the interest rates is the relatively small range of possible interest rates. It can be assumed that banks with very high liquidity ratios can lower the lending rates just to a certain point. The same situation applies for banks being very low on liquidity as these banks can only increase their interest rates up to some limit. For total lending the situation is different. Banks with a very high DLCR can lend as much as possible while banks with a very low DLCR are able to entirely stop lending. 


\section{Conclusion}

The aim of this study is to show the effects of a binding regulatory liquidity requirement on the behavior of banks in the unsecured interbank money market. Our results suggest that a binding regulatory liquidity requirement gives rise to banks paying and asking higher interest rates for unsecured interbank loans. These effects are particularly large for maturities longer than the LCR's 30 day horizon. During a crisis, being just above/below the prudential liquidity requirement induces a negative impact on lending volumes, even when controlling for relationship lending and the riskiness of the borrowing counterparts.

It is essential to note that there are important interactions between our results. Both, interest rates and actual volumes jointly determine the behavior of a bank in the unsecured interbank money market. As established by our results, the general effect of a quantitative liquidity rule on interest rates is a combination of banks asking (paying) higher prices in general but especially during stress. For lending volumes, the main effect of the quantitative liquidity rule is exerted during stress, given that banks for which the rule is binding cut lending more drastically than their peers. Combining the results therefore leads to the conclusion that the negative effect of a quantitative liquidity rule on the interbank money market is particularly severe during stress.

When interpreting our results, the positive implications of a liquidity requirement have to be taken into account as well. A quantitative liquidity requirement leads to a more stable and less vulnerable banking system which is likely to outweigh negative implications to a certain extent. Further, some negative implications of the LCR on the unsecured interbank money market are intended, given that this market was a critical source of contingent liquidity risk during the past crisis.

However, despite its large risk for contingency liquidity, the unsecured interbank money market is an essential instrument for the distribution and allocation of liquidity. Therefore, although the reduced dependence of banks on interbank funding is justifiably intended, regulators should have an incentive to tackle the negative implications of the LCR on monetary policy and clarify the usage of the LCR's liquidity buffer alongside with establishing an extended buffer definition during stress. 


\begin{abstract}
Allowing banks to use their liquidity buffer during stress would dampen the negative effects of a quantitative liquidity requirement on the interbank money market. The reason for this is that if banks can use their liquid assets to cover outflows (as actually intended by the LCR), the liquidity requirement would be less binding with banks facing less incentives to increase interest rates and cut lending. A similar effect can be expected when extending the definition of liquid assets during stress. A potential extension would make it easier for banks to comply with their liquidity requirement, again making the rule less binding and therefore reduce its negative effects during stress on the interbank money market and more importantly on the effectiveness of monetary policy.
\end{abstract}




\section{References}

Akram, Q. and Christophersen, C. (2010). Interbank overnight interest rates - Gains from systemic importance. Norges Bank Working Paper Series, 11.

Ashcraft, A. and Bleakley, H. (2006). On the market discipline of informationally opaque firms : Evidence from bank borrowers in the federal funds market. Federal Reserve Bank of New York Staff Reports, 257.

Aspachs, O., Nier, E., and Tiesset, M. (2005). Liquidity, banking regulation and the macroeconomy: Evidence on bank liquidity holdings from a panel of UK resident banks. Unpublished manuscript, BIS.

Bartolini, L., Bertola, G., and Prati, A. (2001). Banks' reserve management, transaction costs, and the timing of federal reserve intervention. Journal of Banking and Finance, 25:1287-1317.

BCBS (2010a). International framework for liquidity risk management, standards and monitoring. Basel Committee on Banking Supervision.

BCBS (2010b). Strengthening the resilience of the banking sector. Basel Committee on Banking Supervision.

Berger, A. and Bouwman, C. (2009). Bank liquidity creation. Review of Financial Studies, 22:3779-3837.

Bindseil, U. and Lamoot, J. (2011). The basel iii framework for liquidity standards and monetary policy implementation. Humboldt-Universität zu Berlin SFB 649 Discussion Paper, 2011-041.

Borio, C. E. V. (2001). Comparing monetary policy operating procedures across the United States, Japan and the Euro area. BIS Papers, 9.

Braeuning, F. (2011). Relationship lending and peer monitoring: Evidence from interbank payment data. Working Paper.

Cocco, J., Gomes, F., and Martins, N. (2009). Lending relationships in the interbank market. Journal of Financial Intermediation, 18(1):24-48. 
Crotti, J. (2009). Structural causes of the global financial crisis: a critical assessment of the new financial architecture. Cambridge Journal of Economics, 33:563-580.

De Haan, L. and Van den End, J. (2012). Bank liquidity, the maturity ladder, and regulation. DNB Working Paper, 346.

Demiralp, S., Preslopsky, B., and Whitesell, W. (2006). Overnight interbank loan markets. Journal of Economics and Business, 58(1):67-83.

Diamond, D. and Dybvig, P. (1983). Bank runs, deposit insurance, and liquidity. Journal of Political Economy, 91:401-419.

Diamond, D. and Rajan, R. (2009). The credit crisis: Conjectures about causes and remedies. American Economic Review: Papers and Proceedings, 99:2:606-610.

DNB (2003). Regulation on liquidity under the Wft.

Freedman, P. and Click, R. (2009). Banks that do't lend? Unlocking credit to spur growth in developing countries. Development Policy Review, 24;3:279-302.

Furfine, C. (1999). The microstructure of the federal funds market. Financial Markets, Institutions and Instruments, 8:24-44.

Giavazzi, F. and Giovannini, A. (2011). Central banks and the financial system. In Eijffinger, S. and Masciandaro, D., editors, Handbook of Central Banking, Financial Regulation and Supervision - After the Financial Crisis. Edward Elgar Publishing Limited.

Gorton, G. (2009). Information, liquidity, and the (ongoing) panic of 2007. prepared for AER papers and proceedings.

Heijmans, R., Heuver, R., and Walraven, D. (2010). Monitoring the unsecured interbank money market using TARGET2 data. DNB Working Paper, 276.

Hendry, S. and Kamhi, N. (2009). Uncollateralized overnight lending in Canada. Applied Financial Economics, 19(11):869-880.

Hilscher, J. and Wilson, M. (2012). Credit ratings and credit risk. Working Paper. 
Holmstrom, B. and Tirole, J. (2011). Inside and outside liquidity. MIT Press.

Hume, M. and Sentance, A. (2009). The global credit boom: Challenges for macroeconomics and policy. Journal of Economics and Finance, 28:1426-1461.

Jallath-Coria, E., Mukhopadhyay, T., and Yaron, T. (2002). How well do banks manage their reserves? NBER Working Paper, 9388.

MAG (2010a). Assessing the macroeconomic impact of the transition to stronger capital and liquidity requirements. Financial Stability Board and Basel Committee on Banking Supervision (Macroeconomic Assessment Group).

MAG (2010b). Assessing the macroeconomic impact of the transition to stronger capital and liquidity requirements-Final report. Financial Stability Board and Basel Committee on Banking Supervision (Macroeconomic Assessment Group).

Reinhart, C. and Rogoff, K. (2008). Is the 2007 U.S. Sub-Prime financial crisis so different? An international historical comparison. NBER Working Paper, 13671.

Schertler, A. (2010). Insight on bank's liquidity management: Evidence from regulatory liquidity data. Beitraege zur Jahrestagung des Vereins fuer Sozialpolitik 2010.

Schmitz, S. (2009). Liquidity stress tests and regulation. Presented at the conference RiskMinds 2009, Geneva.

Schmitz, S. (2010). The new Basel liquidity standards and their implementation into EU legislation. Presented at the seminar Basel II Enhancements, Bank for International Settlements.

Schmitz, S. (2011). The impact of the Basel 3 liquidity standards on the implementation of monetary policy. Unpublished Working Paper.

Shrieves, R. and Dahl, D. (1992). The relationship between risk and capital in commercial banks. Journal of Banking and Finance, 16:439-457. 
Table .3: Effects of a quantitative liquidity rule on the BORROWING rates in the interbank money market

\begin{tabular}{|c|c|c|c|c|c|c|}
\hline VARIABLES & $\begin{array}{l}\text { (1) } \\
\mathrm{FE}\end{array}$ & $\begin{array}{l}(2) \\
\mathrm{FE}\end{array}$ & $\begin{array}{l}\text { (3) } \\
\mathrm{FE}\end{array}$ & $\begin{array}{l}\text { (4) } \\
\mathrm{FE}\end{array}$ & $\begin{array}{l}(5) \\
\mathrm{FE}\end{array}$ & $\begin{array}{l}\text { (6) } \\
\mathrm{FE}\end{array}$ \\
\hline LOW & $\begin{array}{c}0.206 * * * \\
(0.0293)\end{array}$ & $\begin{array}{c}0.154 * * * \\
(0.0285)\end{array}$ & $\begin{array}{c}0.229 * * * \\
(0.0812)\end{array}$ & $\begin{array}{c}0.211^{* *} \\
(0.0852)\end{array}$ & $\begin{array}{c}0.265 * * * \\
(0.0983)\end{array}$ & $\begin{array}{c}0.259 * * * \\
(0.0983)\end{array}$ \\
\hline LOWcrisis & & $\begin{array}{l}0.0596 \\
(0.0619)\end{array}$ & $\begin{array}{l}0.0503 \\
(0.0643)\end{array}$ & $\begin{array}{l}0.0983 \\
(0.0646)\end{array}$ & $\begin{array}{l}0.0468 \\
(0.0756)\end{array}$ & $\begin{array}{l}0.0751 \\
(0.0776)\end{array}$ \\
\hline crisis & & $\begin{array}{c}-0.478 * * * \\
(0.0254)\end{array}$ & $\begin{array}{c}-0.463 * * * \\
(0.0272)\end{array}$ & $\begin{array}{c}-0.475 * * * \\
(0.0287)\end{array}$ & $\begin{array}{c}-0.478 * * * \\
(0.0298)\end{array}$ & $\begin{array}{c}-0.444 * * * \\
(0.0364)\end{array}$ \\
\hline LongBor & & & $\begin{array}{c}0.396 * * * \\
(0.0447)\end{array}$ & $\begin{array}{c}0.302 * * * \\
(0.0484)\end{array}$ & $\begin{array}{c}0.331 * * * \\
(0.0492)\end{array}$ & $\begin{array}{c}0.338 * * * \\
(0.0494)\end{array}$ \\
\hline LongBorLOW & & & $\begin{array}{c}-0.0624 \\
(0.101)\end{array}$ & $\begin{array}{c}-0.00591 \\
(0.106)\end{array}$ & $\begin{array}{c}-0.0562 \\
(0.123)\end{array}$ & $\begin{array}{c}-0.0569 \\
(0.123)\end{array}$ \\
\hline RLAT & & & & $\begin{array}{c}-0.252 * * * \\
(0.0493)\end{array}$ & $\begin{array}{c}-0.167 * * * \\
(0.0520)\end{array}$ & $\begin{array}{c}-0.127 * * \\
(0.0577)\end{array}$ \\
\hline Capital & & & & & $\begin{array}{l}0.000330 \\
(0.000236)\end{array}$ & $\begin{array}{l}0.000333 \\
(0.000236)\end{array}$ \\
\hline RLATcrisis & & & & & & $\begin{array}{l}-0.177 \\
(0.109)\end{array}$ \\
\hline Constant & $\begin{array}{c}0.858 * * * \\
(0.0110)\end{array}$ & $\begin{array}{c}0.942 * * * \\
(0.0111)\end{array}$ & $\begin{array}{c}0.656 * * * \\
(0.0363)\end{array}$ & $\begin{array}{c}0.769 * * * \\
(0.0414)\end{array}$ & $\begin{array}{c}0.735 * * * \\
(0.0426)\end{array}$ & $\begin{array}{c}0.724 * * * \\
(0.0432)\end{array}$ \\
\hline Observations & 2391 & 2391 & 1978 & 1668 & 1513 & 1513 \\
\hline r2_w & 0.0206 & 0.166 & 0.208 & 0.240 & 0.246 & 0.247 \\
\hline
\end{tabular}

